Title: The antiepileptogenic effect of low-frequency stimulation on perforant path kindling involves changes in regulators of G-protein signaling in rat

Authors: Simin Namvar ${ }^{\mathrm{a}}$, Yaghoub Fathollahi ${ }^{\mathrm{a}}$, Mohammad Javan ${ }^{\mathrm{a}}$, Maryam Zeraati ${ }^{\mathrm{a}}$, Mohammad Mohammad-Zadeh $^{\mathrm{b}}$, Amir Shojaei $^{\mathrm{a}}$, Javad Mirnajafi-Zadeh ${ }^{\mathrm{a}^{*}}$ 


\title{
List of abbreviations
}

\begin{abstract}
ADD: Afterdischarge duration
cAMP: Cyclic adenosine monophosphate

RGS: Regulators of G-protein signaling

KLFS: Kindled+LFS
\end{abstract}

LFS: Low frequency stimulation

LTP: Long term potentiation

pEPSP: Population excitatory post-synaptic potential

PS: Population spike 


\section{Abstract}

G-protein coupled receptors may have a role in mediating the antiepileptogenic effect of low-frequency stimulation (LFS) on kindling acquisition. This effect is accompanied by changes at the intracellular level of cAMP. In the present study, the effect of rolipram as a phosphodiesterase inhibitor on the antiepileptogenic effect of LFS was investigated. Meanwhile, the expression of $\alpha_{s^{-}}$and $\alpha_{i}$-subunit of $G$ proteins and regulators of G-protein signaling (RGS) proteins following LFS application was measured. Male Wistar rats were kindled by perforant path stimulation in a semi-rapid kindling manner (12 stimulations per day) during a period of 6 days. Application of LFS (0.1 ms pulse duration at $1 \mathrm{~Hz}, 200$ pulses, $50-150 \mu \mathrm{A}, 5$ min after termination of daily kindling stimulations) to the perforant path retarded the kindling development and prevented the kindling-induced potentiation and kindling-induced changes in paired pulse indices in the dentate gyrus. Intra-cerebroventricular microinjection of rolipram $(0.25 \mu \mathrm{M})$ partially prevented these LFS effects. Twenty-four hours after the last kindling stimulation, the dentate gyrus was removed and changes in protein expression were measured by Western blotting. There was no significant difference in the expression of $\alpha$-subunit of $G_{s}$ and $G_{i / 0}$ proteins in different experimental groups. However, application of LFS during the kindling procedure decreased the expression RGS4 and RGS10 proteins (that reduce the activity of $\mathrm{G}_{\mathrm{i} / \mathrm{o}}$ ) and prevented the kindling-induced decrease of RGS2 protein (which reduces the $\mathrm{G}_{\mathrm{s}}$ activity). Therefore, it can be postulated that the $\mathrm{G}_{\mathrm{i} / \mathrm{o}}$ protein signaling pathways may be involved in antiepileptogenetic effect of LFS, and this is why decreasing the cAMP metabolism by rolipram attenuates this effect of LFS.

Keywords: Seizure; Brain stimulation; Regulators of G-protein signaling; Dentate gyrus 


\section{Introduction}

Epilepsy is a prevalent neurological disorder. Approximately ten percent of people have at least one epileptic seizure during their lifetime, and a third of these will develop epilepsy (Engel JR and Pedley, 2008). Unfortunately, 30 to $40 \%$ of epileptic patients are resistant to current drug therapy (Schiller and Bankirer, 2007; Picot et al., 2008; Shahpari et al., 2012). Therefore, it is necessary to develop alternative therapeutic techniques. Deep brain stimulation (DBS) has been considered a possible therapy for epilepsy for more than 30 years. Recently, DBS has been approved by the U.S. Food and Drug Administration (FDA) (2013), and now DBS is moving to the point of clinical utility, especially for drug-resistant epilepsies (Gaito, 1980, 1981; Loddenkemper et al., 2001; Li and Mogul, 2007; Montgomery and Gale, 2008; Lockman and Fisher, 2009).

Mounting evidence shows that the application of deep brain stimulation in the form of low-frequency electrical stimulation (LFS) has therapeutic effects in both epileptic patients (Jerger and Schiff, 1995; Albensi et al., 2004) and experimental models of epilepsy, including kindling (Velisek et al., 2002; Goodman et al., 2005; Schrader et al., 2006). Although brain stimulation has been used since ancient times for treatment of different brain disorders (Schwalb and Hamani, 2008), its therapeutic mechanisms have not been completely understood. It has been suggested that the mechanisms involved in depotentiation or long-term depression may have a role in the anticonvulsant effects of LFS. However, there are few studies addressing the antiepileptogenic mechanisms of LFS when it is applied during kindling acquisition.

Our previous studies showed that activation of two G protein-coupled receptors, (adenosine $A_{1}$ and galanin GalR1 and GalR2) may have a role in mediating the anticonvulsant action of LFS in perforant path kindling (Sadegh et al., 2007; Jahanshahi 
et al., 2009; Mohammad-Zadeh et al., 2009). We reported that the antiepileptogenic effects of LFS on perforant path kindling are exerted through activation of adenosine $A_{1}$ receptors (Jahanshahi et al., 2009; Mohammad-Zadeh et al., 2009) and are accompanied with prevention of the kindling-induced increase in cAMP levels (Mohammad-Zadeh et al., 2009). There is a strong relationship between cAMP concentration and seizure severity (Myllyla et al., 1975; Kuriyama and Kakita, 1980; Shigeru, 1983). Thus, the agents that affect cAMP levels (e.g. phosphodiesterase, the main enzyme that degrades cAMP and reduces its concentration) (Jeon et al., 2005), may influence LFS' anticonvulsant action. Adenosine receptors also exert their main effects through changes in cAMP levels. Adenosine $A_{1}$ receptors mediate inhibitory neuromodulation by coupling to inhibitory $G_{i / o}$-containing $G$ proteins (for review, see: Boison, 2005; Fredholm et al., 2005; Jacobson and Gao, 2006). Therefore, regulators of G-protein signaling (RGS) proteins, which regulate the activity of G proteins, may be involved in the anticonvulsant actions mediated by adenosine $A_{1}$ receptors (for review, see: Dohlman and Thorner, 1997; Koelle, 1997; Neer, 1997).

RGS proteins modulate the G-proteins function by activating the intrinsic GTPase activity of a subunits, thereby reduce the duration of the activated GTP-bound state of the a subunit and inhibit G-protein function (for review, see: Dohlman and Thorner, 1997; Koelle, 1997; Neer, 1997). There are more than 30 members in the mammalian RGS family (Xie and Martemyanov, 2011), and at least 10 different kinds of RGS proteins are expressed in the brain (Taymans et al., 2002). RGS2, which is expressed at high level in the hippocampus, increases the GTPase activity of $\mathrm{G}_{\text {as }}$ protein. In addition, RGS2 can inhibit adenylyl cyclase and reduce the cytoplasmic concentration of cAMP (Ingi et al., 1998). RGS4 and RGS10 are also expressed at high levels in the 
hippocampus (Nomoto et al., 1997) and dentate gyrus (Gold et al., 1997) respectively. However, they increase GTPase activity of $\alpha$ subunit of $\mathrm{G}_{\mathrm{i} / \mathrm{o}}$ proteins and thus reduce the inhibitory effect of $\mathrm{G}_{\mathrm{i} / \mathrm{o}}$ on adenylyl cyclase and attenuate the decreasing effect of $\mathrm{G}_{\mathrm{i} / \mathrm{o}}$ on cAMP concentration (Gold et al., 1997; Nomoto et al., 1997).

RGS protein expression is influenced by seizures. It has been shown that the gene expression of RGS10 decreases, but of RGS4 increases in the hippocampus following seizure induction (Liang and Seyfried, 2001; Gold et al., 2002). These proteins are also involved in synaptic plasticity (Ingi et al., 1998), presynaptic inhibition and thereby the regulation of neurotransmitter release (Chen and Lambert, 2000). Therefore, any changes in the expression of RGS proteins may have a role in the anticonvulsant action of LFS. In an attempt to make a better definition of cAMP's role as a main molecule involved in $G_{s}$ and/or $G_{i}$ protein-dependent signaling pathway in mediating the antiepileptogenic effect of LFS, first we investigated the effect of rolipram, a phosphodiesterase 4 inhibitor (that leads to an increase in cAMP concentration) on behavioral seizure severity and field potential recording changes following LFS antiepileptogenic action during a semi-rapid perforant path kindling procedure. Then we studied the possible changes in the expression of $G_{s}$ and $G_{i / 0}$ a subunits, RGS2, RGS4 and RGS10 proteins following LFS administration during kindling.

\section{Material and methods}

\section{Animals}

Adult male Wistar rats (8-9 weeks old), obtained from Pasteur institute of Tehran, Iran, were maintained in a colony room kept at a constant temperature on $12 \mathrm{~h}$ light/ 12 h dark schedule. The light phase was started at 7.00 a.m. Animals were individually 
housed in plastic cages with woodchip bedding and permitted free access to food and water. Experiments were done during the same time period (8:00 a.m. to 2:00 p.m.) to avoid the bias of circadian rhythms. This study was carried out in strict accordance with the ethical guidelines set by the "Ethical Committee of Faculty of Medical Sciences, Tarbiat Modares University" that are completely in accord with the "NIH Guide for the Care and Use of Laboratory Animals". All surgeries were performed under sodium pentobarbital anesthesia, and all efforts were made to minimize suffering and the number of used animals.

\section{Surgical procedures}

Surgical procedure was done as explained previously (Mohammad-Zadeh et al., 2007). Under sodium pentobarbital (50 mg/kg, i.p.) anesthesia, animals underwent stereotaxic implantation of a bipolar stimulating electrode in the perforant path (coordinates: A, $-6.9 \mathrm{~mm}$; L, $4.1 \mathrm{~mm}$; and, $\mathrm{V}, 2-2.5 \mathrm{~mm}$ below dura) and a monopolar recording electrode in the dentate gyrus (coordinates: $A,-2.8 \mathrm{~mm}$; L, $1.8 \mathrm{~mm}$; and, V, 2.5-3 $\mathrm{mm}$ below dura) of the right hemisphere (Paxinos and Watson, 2007). Electrodes (stainless steel, teflon coated, $127 \mu \mathrm{m}$ in diameter, A.M. Systems Inc., USA) were insulated except at their tips. The depth of the recording and stimulating electrodes was adjusted to maximize the population spike (PS) amplitude in the dentate gyrus in response to the perforant-path stimulation. Selective stimulation of the perforant path afferent fibers was confirmed by observing the paired pulse depression in response to paired pulses separated by $30-50 \mathrm{~ms}$ and recording the paired pulse facilitation in response to paired pulse stimulation with interpulse interval of $70 \mathrm{~ms}$. 


\section{Stimulation and recording}

The electrophysiological recordings were performed after the animal was transferred from the home cage to the recording box $(30 \times 30 \times 30 \mathrm{~cm})$ placed in a Faraday's cage. The rat was allowed to move freely in the recording box when its headstage was connected to a flexible, shielded cable. Evoked responses were collected while the rat was motionless and awake with its eyes open. Input/output test was performed to determine the test pulse intensity used in the subsequent experiments. For input/output test, single $0.1 \mathrm{~ms}$ monophasic square wave pulses were delivered to the perforant path through a Nihon Kohden stimulator (Japan, Tokyo) and a Nihon Kohden SS-202J constant-current stimulus isolation unit (Japan, Tokyo) every $10 \mathrm{~s}$ at different intensities $(100 \mu \mathrm{A}-800 \mu \mathrm{A})$ while the evoked field potentials were monitored in the dentate gyrus.

For each time-point, twelve evoked responses were averaged. Both populationexcitatory post-synaptic potential (pEPSP) slope and PS amplitude were monitored. The slope of pEPSP was determined at a fixed interval beginning approximately $0.25 \mathrm{~ms}$ after response onset and continuing within approximately $0.20 \mathrm{~ms}$ before PS onset. The 
PS amplitude was calculated by averaging the height from the peak of the pEPSP to maximum downward deflection of the PS (i.e. $(b+c) / 2$ in right upper trace in Fig. $3 A$ ). By means of input/output test the maximum PS amplitude was determined for each individual animal. All potentials employed as baseline criteria were evoked at a stimulus intensity which produced $50 \%$ of this maximum response (i.e., test pulse). The measured test pulse for different animals was between 100-500 $\mu \mathrm{A}$. The evoked responses were continuously monitored, amplified and digitized (at $10 \mathrm{kHz}$ ) using a PCbased data acquisition system (D3107; ScienceBeam Co., Tehran, Iran). Then, they were averaged and finally stored on hard disk using a custom designed software (ScienceBeam Co., Tehran, Iran).

\section{Semi-rapid kindling procedures}

The semi-rapid kindling procedure was done as previously explained (MohammadZadeh et al., 2007; Sadegh et al., 2007). After ten days post-surgical recovery, the afterdischarge (AD) threshold was determined by $1 \mathrm{~ms}$ monophasic square wave of 50 $\mathrm{Hz}$ with $3 \mathrm{~s}$ train duration. The stimuli were initially delivered at $30 \mu \mathrm{A}$ and then the stimulus intensity was increased in $10 \mu \mathrm{A}$ steps at 5 min intervals. The minimum intensity sufficient to induce $A D$ for at least $8 \mathrm{~s}$ was designated as the $A D$ threshold, and used for stimulation. The $A D$ threshold intensity ranged from 50 to $150 \mu \mathrm{A}$. Rats were stimulated at the AD threshold twelve times per day at 5 min intervals. The summation of the AD duration (ADD) after 12 daily stimulations was measured and reported in a cumulative manner. The behavioral progression of kindling (stages 1-5; according to Racine scores (Racine, 1972)) was also monitored. 


\section{Paired-pulse test}

After the recovery period, paired pulse tests were run on the $1^{\text {st }}, 3^{\text {rd }}$ and $6^{\text {th }}$ day of kindling acquisition. The intensity of paired pulse stimulations (100-500 $\mu \mathrm{A})$ was set at test pulse and six sweeps were averaged at each of the following 10 interpulse intervals: $10,20,30,40,50,70,100,300,500$ and $1000 \mathrm{~ms}$. These intervals were tested randomly, and pulse pairs were separated by $10 \mathrm{~s}$ intervals $(0.1 \mathrm{~Hz})$. The paired pulse index was calculated as the percent ratio of the second (test) to the first (conditioning) PS amplitude.

\section{Drug administration}

Rolipram (Sigma; St. Louis, MO, USA) was dissolved in DMSO and then diluted in artificial cerebrospinal fluid to the desired concentration so that the final concentration of DMSO was $0.1 \%$. The $\mathrm{pH}$ of the solutions was adjusted to $7.3-7.4$ using $1 \mathrm{~N} \mathrm{NaOH}$. Artificial cerebrospinal fluid contained (in $\mathrm{mM}$ ): $114 \mathrm{NaCl}, 3 \mathrm{KCl}, 1.25 \mathrm{NaH}_{2} \mathrm{PO}_{4}, 2$ $\mathrm{MgSO}_{4}, 26 \mathrm{NaHCO}_{3}, 1 \mathrm{CaCl}_{2}$ and 10 glucose. The solutions were then sterilized through microfilters $(0.2 \mu \mathrm{m}$, Minisart, NML, Sartorius, Germany). The drugs were microinfused ( $1 \mu$ lover 2 min) every day 5 min before animal stimulation by means of a microsyringe pump (Stoelting, USA) via a 30-gauge cannula, which was $1 \mathrm{~mm}$ below the tip of 23-gauge cannula.

\section{Immunoblotting Analysis}

For immunoblotting, animals were sacrificed by decapitation under $\mathrm{CO}_{2}$ anesthesia, and the right dentate gyrus was immediately removed and preserved in liquid nitrogen 
until the day of immunoblotting. The extracted hippocampus was homogenized on ice in cold lysis buffer containing tris hydrochloride, $50 \mathrm{mM}$; NaCl, $150 \mathrm{mM}$; triton X-100, 0.1\%; Sodium Deoxycholate, 0.25\%; EDTA $1 \mathrm{mM}$; SDS, 0.1\%; protease inhibitor $0.1 \%$ (Roche, Germany). After centrifugation, the supernatant was collected and assayed for protein concentration using the Bradford method. The lysates containing equal amounts of protein were resolved on SDS-12.5\% polyacrylamide gel electrophoresis, transferred to PVDF membrane (Amersham Bioscience, Freiburg, Germany), blocked in 2\% ECL advanced kit-blocking reagent (Amersham Bioscience, Freiburg, Germany) and probed with primary rabbit monoclonal antibodies (anti-RGS4, anti-RGS10 (1:1000), anti-Gas and anti-G $\mathrm{G}_{\text {ai }}(1: 750)$, anti-RGS2 (1:500) all from Cell Signaling Technology, Danvers, MA, USA) overnight at $4^{\circ} \mathrm{C}$. After washing, membranes were incubated for $60 \mathrm{~min}$ at room temperature with the horseradish peroxidase-conjugated anti-rabbit antibody (1:10000, Santa Cruz Biotechnology, CA, USA). Blots were subsequently revealed by ECL advanced kit (Amersham Bioscience, Freiburg, Germany). To normalize for protein content of lanes, blots were stripped in stripping buffer containing $100 \mathrm{mM} 2$ - mercaptoethanol, $2 \%(\mathrm{w} / \mathrm{v}) \mathrm{SDS}$, and $62.5 \mathrm{mM}$ Tris- $\mathrm{HCl}(\mathrm{pH} 6.7)$ and then probed with rabbit anti-actin antibody (1:1000, Santa Cruz Biotechnology, CA, USA) (Goudarzvand et al.).

\section{Experimental design}

Animals were divided into control, LFS, kindled and kindled+LFS (KLFS) groups. In kindled groups animals were stimulated according to the rapid kindling protocol and the kindling parameters (including cumulative ADD and seizure stages) were monitored. Field potential parameters were recorded just before kindling stimulations for $20 \mathrm{~min}$. Following the field potential recording, paired pulse indices were also calculated on 
days 1, 3, and 6 (Fig. 1). In the KLFS group, animals followed the same protocol, but LFS (0.1 ms pulse duration at $1 \mathrm{~Hz}, 200$ pulses, and 50-150 $\mu \mathrm{A})$ was applied after termination of kindling stimulations (Fig. 1). LFS parameters were determined according to our previous experiments (Ghorbani et al., 2007; Mohammad-Zadeh et al., 2007). In LFS group, animals received only LFS similar to KLFS group, but no kindling stimulation was applied. Animals in the control group underwent the surgical procedure, without receiving LFS or kindling stimulations.

As mentioned previously, LFS' antiepileptogenic effect is accompanied with prevention of the kindling-induced increase in cAMP levels (Mohammad-Zadeh et al., 2009). Accordingly, in the present study, we used rolipram (as a selective phosphodiesterase IV inhibitor) to determine if inhibiting the reduction in cAMP levels can change the effectiveness of LFS on the kindling procedure. Accordingly, both kindled and KLFS groups were then divided into three main subgroups: (i) no injected groups (kindled and KLFS)that received no chemicals, (ii) vehicle injected groups (kindled+vehicle and KLFS+vehicle) that received vehicle $(1 \mu \mathrm{l}) 5 \mathrm{~min}$ before LFS every day during kindling procedure and (iii) rolipram injected groups (kindled+rolipram and KLFS+rolipram) that received rolipram $(0.25 \mu \mathrm{M}, 1 \mu \mathrm{l})$ instead of 5 min before LFS. Stimulation days continued until the animals showed at least one stage 5 seizure after one of its daily 12 stimulations. The day that a given animal showed stage 5 seizure was considered the last experimental day for that animal. The mean number of stimulation days to achieve stage 5 seizure in the kindled group was $5.6 \pm 1.1$. Thus, the $6^{\text {th }}$ day was considered as the last day of the experiment in KLFS, LFS and control groups. In addition, field potential parameters were monitored during the 6 days of experiments in different groups. At least six rats were used in each group. 
In control, LFS, kindled and KLFS groups, brain sampling was done for Western blotting at $24 \mathrm{~h}$ after the last stimulation of the animal.

\section{Statistical analysis}

Data were averaged and expressed as mean \pm standard error of the mean (S.E.M.) and accompanied by the number of observations. For each time point of field potential recording during the experiment, averages were calculated from the data on twelve (for basal synaptic response experiments) or six (for input/output curve recordings and paired-pulse experiments) successive evoked responses. A mean value of responses at ten time points on day 1 was defined as the baseline (100\%). Subsequent data were expressed as the percent change from the baseline. Two-way ANOVA was used to determine changes in cumulative ADD in the experimental groups during different days. The changes in percent of increase in PS and pEPSP in day 6, paired-pulse index on day 6 , and protein expressions in different experimental groups were compared with one-way ANOVA. Statistically significant differences were evaluated further by a Tukey's post-hoc test. To compare the changes in data of two independent groups, a student unpaired t-test was used. The probability level interpreted as statistically significant was $\mathrm{P}<0.05$.

\section{Results}

Eighteen rats were eliminated from the study because of incorrect position of electrodes and consequent disruption of their electrophysiological responses during freely-moving records. All animals were randomized into four experimental groups and then the $A D$ threshold and test pulse intensity were determined in all of them. 
Subsequent statistical analysis did not show any difference in AD threshold $(76.2 \pm 22.8$ $\mu \mathrm{A}$ and 81.4 $\pm 18.7 \mu \mathrm{A}$ in kindled and KLFS groups respectively) and in test pulse intensity $(348.4 \pm 61.0 \mu \mathrm{A}$ in control, $315.6 \pm 44.2 \mu \mathrm{A}$ in LFS, $298.6 \pm 68.4 \mu \mathrm{A}$ in kindled and $362.7 \pm 51.2 \mu \mathrm{A}$ in KLFS groups) among the groups. This means that there was no difference in synaptic sensitivity and seizure susceptibility of animals at the beginning of experiments.

\section{Effect of rolipram on antiepileptogenic action of LFS during kindling}

\section{acquisition}

The LFS application had a significant anticonvulsant effect on the perforant path kindling procedure as previously described (Ghorbani et al., 2007; Sadegh et al., 2007; Mohammad-Zadeh et al., 2009). The LFS application prevented the progression in seizure stages (Fig. 2A) and cumulative ADD (Fig. 2B). Our previous experiments showed that the application of LFS prevented the increase in cAMP concentration during kindling acquisition (Ghorbani et al., 2007; Mohammad-Zadeh et al., 2009). To confirm the negative relationship between the LFS antiepileptogenic effect and intracellular cAMP levels, rolipram (a phosphodiesterase IV inhibitor) was microinjected into the right cerebral ventricular before the LFS application. Vehicle administration had not any significant effect on measured parameters, and there was no difference between kindled and kindled+vehicle or KLFS and KLFS+vehicle groups in behavioral and electrophysiological parameters. Therefore, the parameters of rolipram-treated animals were compared with the respected vehicle received groups.

Compared to kindled group, microinjection of rolipram $(0.25 \mu \mathrm{M}, 1 \mu \mathrm{l})$ in kindled+rolipram group did not have any significant effect on seizure stages (day 1: 
$1.26 \pm 0.27$ vs $1.23 \pm 0.26$, day $3: 3.49 \pm 0.24$ vs $3.25 \pm 0.24$, day $6: 5.0 \pm 0$ vs $4.99 \pm 0.13$ for kindled+rolipram and kindled+vehicle respectively) and CADD (day 1: 115.45 $\pm 42.80 \mathrm{~s}$ vs $120.93 \pm 22.39$ s, day $3: 202.87 \pm 35.33$ s vs $178.65 \pm 33.51$ s, day $6: 258.78 \pm 39.14$ s vs 271.71 $\pm 22.39 \mathrm{~s})$. In addition, rolipram administration did not alter the kindling-induced changes in PS amplitude (139.46 \pm 5.33 in kindled+rolipram vs $134.61 \pm 6.72$ in kindled+vehicle) and pEPSP slope (178.19 \pm 3.97 in kindled+rolipram vs 166.61 \pm 6.72 in kindled+vehicle) after 6 days. Therefore, we microinjected this non-effective dose of rolipram in the KLFS+rolipram subjects to study the interaction of this chemical with the antiepileptogenic action of LFS. Rolipram declined the inhibitory effect of LFS on kindling development. As Fig. 2A shows, while application of LFS decreased the behavioral seizure stages at $4^{\text {th }}, 5^{\text {th }}$ and $6^{\text {th }}$ day of kindling stimulation, injection of rolipram before LFS application prevented these effects so that the seizure stages in KLFS+rolipram group were similar to kindled group, and the animals achieved stage 5 seizure after 6 days (Fig. 2A). The suppressing effect of LFS on progression of cumulative ADD was also removed by rolipram microinjection. The cumulative ADD in KLFS+vehicle group was $122.8 \pm 29.7$ s, while in KLFS+rolipram it significantly increased to $221.8 \pm 30.3 \mathrm{~s}$ At the $6^{\text {th }}$ day of kindling stimulation $(p<0.05)$ (Fig. $\left.2 B\right)$.

In the presence of rolipram $(0.25 \mu \mathrm{M})$, LFS application could not prevent the kindling induced potentiation in synaptic transmission (Fig 3). As the upper traces of sample records in Fig. 3A show, kindling induced potentiation in perforant path-dentate gyrus synapses. Application of LFS prevented this potentiation during kindling stimulation (Fig. 3A, middle traces). Injection of rolipram reduced the inhibitory effect of LFS on kindling-induced potentiation (Fig. 3A, lower traces). Fig. 3B shows changes in pEPSP and PS amplitude (normalized to day 1 as baseline) in 3 mentioned groups 
during kindling procedure. Despite the strong inhibitory effect of LFS on kindlinginduced potentiation, animals in the KLFS+rolipram group showed synaptic potentiation that was similar to kindled group (Fig. 3B). These changes are shown in Fig. $3 \mathrm{C}$ as the percent of changes in pEPSP or PS amplitude on day 6 .

The rolipram microinjection could also prevent the inhibitory effect of LFS on kindling-induced changes in paired pulse indices (Fig. 4). Similar to previous reports (de Jonge and Racine, 1987; Maru and Goddard, 1987; Gilbert, 1991), kindling produced a potentiation in early and late paired-pulse depression. The LFS application prevented potentiation in both early and late paired-pulse depression and the attenuation in pairedpulse facilitation during the first 6 days of kindling procedure (Fig. 4A). In the presence of rolipram $(0.25 \mu \mathrm{M})$ LFS application could not prevent the potentiation of paired pulse depression and the attenuation of paired pulse facilitation (Fig. 4). Fig. 4B shows the percentage changes of paired pulse indices at the 6th day with respect to the 1 st day. On day 6 , this parameter was near $100 \%$ of the 1 st day in the KLFS+vehicle group. This means that no change was produced in paired pulse indices at different interpulse intervals for 6 days, and LFS prevented the kindling-induced changes in paired pulse indices. In the KLFS+rolipram group, the LFS did not prevent the changes in paired pulse indices (Fig. 4B).

\section{Changes in $\mathrm{G}_{\mathrm{ai}}, \mathrm{G}_{\mathrm{as}}, \mathrm{RGS2,} \mathrm{RGS4}$ and RGS10 proteins expression}

Results of the first experiment showed a probable negative relationship between phosphodiesterase activity (and thereby cAMP level) and LFS antiepileptogenic effects. Considering the role of G proteins in regulation of intracellular cAMP concentration, we measured the effect of the LFS application during kindling development on the levels of 
$\alpha$-subunit of $G_{s}$ and $G_{i / o}$ proteins, as well as the expression of their signaling regulators RGS2, RGS4 and RGS10 by western blotting.

Measuring the band densities by Image $\mathrm{J}$ software (NIH, Bethesda, MD) and their normalization by $\beta$-actin showed that there was no significant difference in the expression of $\alpha$-subunit of $G_{s}$ and $G_{i / 0}$ proteins, so that the ratio of $G_{\alpha s} / G_{a i / o}$ was similar among different experimental groups (Fig 5A-C). However, the expression of RGS2 was significantly decreased in kindled group, but not in the KLFS group (Fig. 5A,D). This means that the LFS application prevented the decrement in RGS2 expression during kindling acquisition. In addition, while there was no significant difference in the expression of RGS4 and RGS10 between kindled and control groups, the application of LFS during kindling significantly decreased the expression of these proteins compared to the control group (Fig 5A,E,F). When administered alone, LFS did not have any significant effect on the expression of the above mentioned proteins compared to the control group.

\section{Discussion}

Obtained results indicated that LFS administration could slow down the acquisition of perforant path rapid kindling seizures. Similar our previous reports (MohammadZadeh et al., 2007; Jahanshahi et al., 2009; Mohammad-Zadeh et al., 2009), more stimulations were needed in animals that received LFS during kindling procedure to achieve higher seizure stages. In addition, their cumulative ADDs during 7 days of stimulations were lower than kindled animals. Meanwhile, kindling-induced potentiation was prevented by LFS. Inhibition of phosphodiesterase (by rolipram) reduced these 
antiepiletogenic effects of LFS and showed a negative relationship between phosphodiesterase activity (and therefore cAMP concentration) and antiepileptogenic action of LFS. These results are in line with studies which showed that CAMP has epileptogenic effect in rats (Kuriyama and Kakita, 1980; Shigeru, 1983; Calabro et al., 2015) and seizure occurrence is accompanied with an increment of cAMP level in cerebrospinal fluid of epileptic patients (Myllyla et al., 1975). Of course, this increment may be either a consequence or a cause of seizures.

Consistent with the present results, our previous studies also showed that the anticonvulsant effects of LFS are accompanied with a decrease in kindling induced elevation of cAMP concentration (Mohammad-Zadeh et al., 2009). Furthermore, activation of $\mathrm{G}_{\mathrm{i} / \mathrm{o}}$ protein coupled receptors (which leads to the decrease of cAMP production), such as adenosine $A_{1}$ (Mohammad-Zadeh et al., 2009) and galanin GalR1 and GalR2 receptors (Sadegh et al., 2007) are involved in mediating the inhibitory action of LFS on kindled seizures. These studies confirm the negative relationship between cAMP concentration and the anticonvulsant effect of LFS.

The inhibitory action of LFS on kindling-induced synaptic potentiation was reduced following injection of rolipram. Previous studies showed that the cAMP dependent signal transduction pathway is an essential component in synaptic potentiation and LTP (Huang et al., 1996; Zhang et al., 2011). In the Schaffer collateral-CA1 pathway, application of Sp-cAMPS, an activator of protein kinase A induces LTP, which lasts for several hours (Frey et al., 1993). Rolipram can also facilitate the LTP induction in CA1 region of hippocampal slices (Barad et al., 1998; Navakkode et al., 2004). In addition, phosphodiesterase inhibition can potentiate and extend LTP at the CA3-CA1 synapse in response to a stimulus that normally induces LTP (Barad et al., 1998). Meanwhile, 
application of forskolin, an adenylyl cyclase activator, during LFS application suppressed depotentiation in brain slices (Huang et al., 1999; Chen et al., 2001). Considering the similarities between kindling induced synaptic potentiation and LTP (Cain, 1989), a similar role may be considered for cAMP in these two phenomena. Therefore, a decrease in cAMP level may be considered as a possible mechanism for LFS antiepileptogenesis effect. However, rolipram only partially abolished the effects of LFS on kindling. This may suggest the presence of other mechanisms underlying the LFS action. For example, we have recently found the involvement of MAP-kinase pathway in mediating LFS effects (unpublished data).

The potentiation of early and late paired pulse depression in the dentate gyrus was suppressed by the application of LFS during kindling procedure. Microinjection of rolipram significantly reduced theses effects of LFS. As we discussed previously (Mohammad-Zadeh et al., 2007), a GABA $_{A}$ receptors-mediated recurrent feedback inhibition is involved in early paired pulse depression (Adamec et al., 1981; Tuff et al., 1983) and a $\mathrm{GABA}_{\mathrm{B}}$ receptors and/or calcium dependent afterhyperpolarizationmediated late paired pulse depression implicates a feedforward inhibition (Thalmann and Ayala, 1982; Alger, 1984). The observed increase in early and late paired-pulse indices shows that kindling can potentiate the GABAergic currents as a compensatory mechanism against neuronal activity. The other factor which can reduce the paired pulse indices during kindling may be an increase in the neurotransmitter releasing probability. According to the data in the present study, we can suggest that the inhibitory effects of LFS on kindling-induced potentiation of early and late paired pulse depression, or kindling-induced elevation in neurotransmitter realizing probability, depends on the reduction of cAMP level. 
Considering the main role of Gi/s proteins in regulation of cAMP level, we expected to observe a significant change in the expression of these proteins among different experimental groups. However, our data showed significant alteration in expression of neither $\alpha_{s}$ nor $\alpha_{i}$ subunit of $G$ proteins. These results are not inconsistent with the previous reports that showed an increase in the expression of $\alpha$ subunit of $G_{0}$ protein in dentate gyrus of amygdala kindled rats (Lason and Przewlocki, 1994) and a decrease in immunoreactivity levels of $\alpha$ subunit of $\mathrm{G}_{\mathrm{i} / \mathrm{o}}$ protein in amygdala, piriform cortex and hippocampus at $24 \mathrm{~h}$ post seizure (Cutz et al., 1996). On the other hand, pharmacological studies have shown that $\mathrm{G}_{\mathrm{i} / \mathrm{o}}$ protein-coupled receptors (such as metabotropic glutamatergic receptors) are involved in the inhibitory effects of LFS on synaptic strength (Upreti et al.; Xu et al., 2010; Atwood et al., 2014). Our previous studies also showed the involvement of adenosine $A_{1}$ and galanin (GALR1 and GALR2) receptors in mediating the antiepileptogenic effects of LFS in kindling (Sadegh et al., 2007; Mohammad-Zadeh et al., 2009). Therefore, it can be suggested that changes in the a subunit of G proteins have a role in epileptogenesis. Of course, it must be noted that we only measured the protein expression of $\alpha$ subunits, while the enzyme activity can be a better parameter in determining the changes in $\alpha_{s} / \alpha_{i}$ activity following LFS application during kindling procedure. It may be postulated that an increase in the ratio of $\mathrm{G}_{\mathrm{o} / \mathrm{l}} / \mathrm{G}_{\mathrm{s}}$ proteins activation has an important role in anticonvulsant action of LFS.

An interesting finding of our experiments was that application of LFS during kindling decreased the expression RGS4 and RGS10 proteins in KLFS group and prevented the decrease in RGS2 expression in the kindled group. These proteins are involved in synaptic plasticity (Ingi et al., 1998; Lerner and Kreitzer, 2012; Gerber et al., 2016), 
presynaptic inhibition and thereby the regulation of neurotransmitters' release (Chen and Lambert, 2000). In addition, their gene expression is influenced by seizures.

While we observed a decrease in the amount of RGS2 protein, a previous study reported an increase in the mRNA levels of RGS2 at $2 \mathrm{~h}$ after acute electroconvulsive seizures (Gold et al., 2002). This discrepancy may be because of difference in the experimental model of seizures and the post-seizure time elapsed. In addition, we measured the level of protein, not the expression of mRNA. RGS2 protein has a role in synaptic transmission and plasticity. RGS2 can determine short-term (Han et al., 2006) and long-term synaptic plasticity (Hutchison et al., 2009) in the hippocampus. Considering the facts that RGS2 has a negative effect on $\mathrm{G}_{\mathrm{s}}$ protein activity, and activation of $\mathrm{G}_{\mathrm{s}}$ protein can increase cAMP as a proconvulsive agent, it is logical to assume that the decrement of RGS2 protein observed in the present study can help epileptogenesis. Therefore, preventing the decrease of RGS2 following an LFS application can help LFS to exert its antiepileptogenic effect (Fig 6).

Although we did not observe any significant changes in the level of RGS4 and RGS10 proteins in kindled animals, previous studies have shown that RGS10 gene expression decreases $24 \mathrm{~h}$ after acute electroconvulsive seizure, but gene expression of RGS4 protein increases in the hippocampus following rapid kindling seizures (Liang and Seyfried, 2001; Gold et al., 2002). A prolonged change in expression of RGS4 is also reported in response to rapid kindling (Liang and Seyfried, 2001). Again, the variation in experimental models and the seizure severity may be the reason for the observed difference. In our experiments the animals of kindled group showed stage 5 seizure; however, animals in rapid kindling model showed an average stage of 3.4 , and in another study, the seizure model was acute. RGS4 and RGS10 proteins have also 
role in synaptic transmission. RGS4 takes part in mediating of long-term depression (Lerner and Kreitzer, 2012). This protein also modulates signaling of several $\mathrm{G}_{\mathrm{aq}^{-}}$ coupled receptors, including metabotropic glutamate receptor (Schwendt and McGinty, 2007). In addition, it has been shown that RGS4 and RGS10 proteins may play an important role in determining the intensity and specificity of signaling pathways in brain as well as their adaptations to synaptic activity (Gold et al., 1997). A corresponding decrease in RGS4 and RGS10 protein levels would be expected to result in the facilitation of $\mathrm{G}_{\mathrm{i} / \mathrm{o}}$-mediated receptor signaling, which could in turn result in a decrease in cAMP level and present an inhibitory response to kindling induced synaptic potentiation (Fig. 6).

When it was applied alone, LFS had no significant effect on expression of different proteins. However, when LFS was administered following kindling stimulations, it prevented kindling-induces changes in RGS2, RGS 4 and RGS 10 protein expression. These differences are in accordance with the antiepileptogenic effects of LFS. In fact, LFS had inhibitory effect on all aspects of kindling development, including the changes in level of proteins which may have a role in progression of kindled seizures.

\section{Conclusion}

In conclusion, obtained results in combined with our previous experiments (Sadegh et al., 2007; Jahanshahi et al., 2009; Mohammad-Zadeh et al., 2009) show a possible role for $\mathrm{G}_{\mathrm{i} / \mathrm{o}}$ protein activation in mediating the antiepileptogenic effects of LFS. We summarized this information in figure 6 . As the figure shows, it is possible to suggest that the situations which increase the $\mathrm{G}_{\mathrm{i} / \mathrm{o}} / \mathrm{G}_{\mathrm{s}}$ protein activity may be involved in mediating the antiepileptogenic effect of LFS. However, more experiments are need to determine the role of $\mathrm{G}$ proteins in LFS anticonvulsant actions. 


\section{Acknowledgments}

This work was done entirely at the Department of Physiology, School of Medical

Sciences, and was supported by grants from Tarbiat Modares University and Iran

National Science Foundation (grant \# 87020353).

"None of the authors have any conflicts of interest to disclose." 


\section{References}

Adamec RE, McNaughton B, Racine R, Livingston KE (1981) Effects of diazepam on hippocampal excitability in the rat: action in the dentate area. Epilepsia 22:205-215.

Administration USFaD (2013) Press Announcements - FDA approves medical device to treat epilepsy [cited 2016 May 26]. Available from:

URL:http://www.fda.gov/NewsEvents/Newsroom/PressAnnouncements/ucm375041 .htm.

Albensi BC, Ata G, Schmidt E, Waterman JD, Janigro D (2004) Activation of long-term synaptic plasticity causes suppression of epileptiform activity in rat hippocampal slices. Brain Res 998:56-64.

Alger BE (1984) Characteristics of a slow hyperpolarizing synaptic potential in rat hippocampal pyramidal cells in vitro. J Neurophysiol 52:892-910.

Atwood BK, Lovinger DM, Mathur BN (2014) Presynaptic long-term depression mediated by Gi/o-coupled receptors. Trends Neurosci 37:663-673.

Barad M, Bourtchouladze R, Winder DG, Golan H, Kandel E (1998) Rolipram, a type IVspecific phosphodiesterase inhibitor, facilitates the establishment of long-lasting long-term potentiation and improves memory. Proc Natl Acad Sci U S A 95:1502015025.

Boison D (2005) Adenosine and epilepsy: from therapeutic rationale to new therapeutic strategies. Neuroscientist 11:25-36.

Cain DP (1989) Long-term potentiation and kindling: how similar are the mechanisms? Trends Neurosci 12:6-10.

Calabro RS, De Luca R, Balletta T, Russo M, Naro A, Bramanti P (2015) Seizureinduced by phosphodiesterase -5 inhibitors for recreational use: an emerging problem among young people! Subst Use Misuse 50:137-138.

Chen H, Lambert NA (2000) Endogenous regulators of $\mathrm{G}$ protein signaling proteins regulate presynaptic inhibition at rat hippocampal synapses. Proc Natl Acad Sci U S A 97:12810-12815.

Chen YL, Huang CC, Hsu KS (2001) Time-dependent reversal of long-term potentiation by low-frequency stimulation at the hippocampal mossy fiber-CA3 synapses. J Neurosci 21:3705-3714. 
Cutz JC, Li PP, Burnham WM, Warsh JJ (1996) Brain region-specific and timedependent decreases of $\mathrm{G}$ alpha i2 in amygdala-kindled rats. Synapse 22:226-231. de Jonge M, Racine RJ (1987) The development and decay of kindling-induced increases in paired-pulse depression in the dentate gyrus. Brain Res 412:318-328.

Dohlman HG, Thorner J (1997) RGS proteins and signaling by heterotrimeric G proteins. J Biol Chem 272:3871-3874.

Engel JR J, Pedley TA (2008) Introduction: What is epilepsy? In: Epilepsy: a comprehensive textbook, vol. 1 (Engel JR, J. and Pedley, T. A.eds), pp 1-6 Philadelphia: Lippincott Williams \& Wilkins.

Fredholm BB, Chen JF, Cunha RA, Svenningsson P, Vaugeois JM (2005) Adenosine and brain function. Int Rev Neurobiol 63:191-270.

Frey U, Huang YY, Kandel ER (1993) Effects of cAMP simulate a late stage of LTP in hippocampal CA1 neurons. Science 260:1661-1664.

Gaito J (1980) The effect of variable duration one hertz interference on kindling. Can J Neurol Sci 7:59-64.

Gaito J (1981) The effect of low frequency and direct current stimulation on the kindling phenomenon in rats. Can J Neurol Sci 8:249-253.

Gerber KJ, Squires KE, Hepler JR (2016) Roles for Regulator of G Protein Signaling Proteins in Synaptic Signaling and Plasticity. Mol Pharmacol 89:273-286.

Ghorbani P, Mohammad-Zadeh M, Mirnajafi-Zadeh J, Fathollahi Y (2007) Effect of different patterns of low-frequency stimulation on piriform cortex kindled seizures. Neurosci Lett 425:162-166.

Gilbert ME (1991) Potentiation of inhibition with perforant path kindling: an NMDAreceptor dependent process. Brain Res 564:109-116.

Gold SJ, Heifets BD, Pudiak CM, Potts BW, Nestler EJ (2002) Regulation of regulators of $G$ protein signaling mRNA expression in rat brain by acute and chronic electroconvulsive seizures. J Neurochem 82:828-838.

Gold SJ, Ni YG, Dohlman HG, Nestler EJ (1997) Regulators of G-protein signaling (RGS) proteins: region-specific expression of nine subtypes in rat brain. J Neurosci 17:8024-8037. 
Goodman JH, Berger RE, Tcheng TK (2005) Preemptive low-frequency stimulation decreases the incidence of amygdala-kindled seizures. Epilepsia 46:1-7.

Goudarzvand M, Javan M, Mirnajafi-Zadeh J, Mozafari S, Tiraihi T Vitamins E and D3 attenuate demyelination and potentiate remyelination processes of hippocampal formation of rats following local injection of ethidium bromide. Cell Mol Neurobiol 30:289-299.

Han J, Mark MD, Li X, Xie M, Waka S, Rettig J, Herlitze S (2006) RGS2 determines short-term synaptic plasticity in hippocampal neurons by regulating Gi/o-mediated inhibition of presynaptic Ca2+ channels. Neuron 51:575-586.

Huang CC, Liang YC, Hsu KS (1999) A role for extracellular adenosine in timedependent reversal of long-term potentiation by low-frequency stimulation at hippocampal CA1 synapses. J Neurosci 19:9728-9738.

Huang YY, Nguyen PV, Abel T, Kandel ER (1996) Long-lasting forms of synaptic potentiation in the mammalian hippocampus. Learn Mem 3:74-85.

Hutchison RM, Chidiac P, Leung LS (2009) Hippocampal long-term potentiation is enhanced in urethane-anesthetized RGS2 knockout mice. Hippocampus 19:687691.

Ingi $\mathrm{T}$, Krumins AM, Chidiac $\mathrm{P}$, Brothers GM, Chung S, Snow BE, Barnes CA, Lanahan AA, Siderovski DP, Ross EM, Gilman AG, Worley PF (1998) Dynamic regulation of RGS2 suggests a novel mechanism in G-protein signaling and neuronal plasticity. J Neurosci 18:7178-7188.

Jacobson KA, Gao ZG (2006) Adenosine receptors as therapeutic targets. Nat Rev Drug Discov 5:247-264.

Jahanshahi A, Mirnajafi-Zadeh J, Javan M, Mohammad-Zadeh M, Rohani R (2009) The antiepileptogenic effect of electrical stimulation at different low frequencies is accompanied with change in adenosine receptors gene expression in rats. Epilepsia 50:1768-1779.

Jeon YH, Heo YS, Kim CM, Hyun YL, Lee TG, Ro S, Cho JM (2005)

Phosphodiesterase: overview of protein structures, potential therapeutic applications and recent progress in drug development. Cell Mol Life Sci 62:11981220. 
Jerger K, Schiff SJ (1995) Periodic pacing an in vitro epileptic focus. J Neurophysiol 73:876-879.

Koelle MR (1997) A new family of G-protein regulators - the RGS proteins. Curr Opin Cell Biol 9:143-147.

Kuriyama K, Kakita K (1980) Cholera toxin induced epileptogenic focus: an animal model for studying roles of cyclic AMP in the establishment of epilepsy. Prog Clin Biol Res 39:141-155.

Lason W, Przewlocki R (1994) Seizure-induced expression of G proteins in the rat hippocampus. Brain Res Mol Brain Res 24:65-69.

Lerner TN, Kreitzer AC (2012) RGS4 is required for dopaminergic control of striatal LTD and susceptibility to parkinsonian motor deficits. Neuron 73:347-359.

Li Y, Mogul DJ (2007) Electrical control of epileptic seizures. J Clin Neurophysiol 24:197-204.

Liang D, Seyfried TN (2001) Genes differentially expressed in the kindled mouse brain. Brain Res Mol Brain Res 96:94-102.

Lockman J, Fisher RS (2009) Therapeutic brain stimulation for epilepsy. Neurol Clin 27:1031-1040.

Loddenkemper T, Pan A, Neme S, Baker KB, Rezai AR, Dinner DS, Montgomery EB, Jr., Luders HO (2001) Deep brain stimulation in epilepsy. J Clin Neurophysiol 18:514-532.

Maru E, Goddard GV (1987) Alteration in dentate neuronal activities associated with perforant path kindling. I. Long-term potentiation of excitatory synaptic transmission. Exp Neurol 96:19-32.

Mohammad-Zadeh M, Mirnajafi-Zadeh J, Fathollahi Y, Javan M, Ghorbani P, Sadegh M, Noorbakhsh SM (2007) Effect of low frequency stimulation of perforant path on kindling rate and synaptic transmission in the dentate gyrus during kindling acquisition in rats. Epilepsy Res 75:154-161.

Mohammad-Zadeh M, Mirnajafi-Zadeh J, Fathollahi Y, Javan M, Jahanshahi A, Noorbakhsh SM, Motamedi F (2009) The role of adenosine A(1) receptors in mediating the inhibitory effects of low frequency stimulation of perforant path on kindling acquisition in rats. Neuroscience 158:1632-1643. 
Montgomery EB, Jr., Gale JT (2008) Mechanisms of action of deep brain stimulation(DBS). Neurosci Biobehav Rev 32:388-407.

Myllyla VV, Heikkinen ER, Vapaatalo H, Hokkanen E (1975) Cyclic amp concentration and enzyme activities of cerebrospinal fluid in patients with epilepsy or central nervous system damage. Eur Neurol 13:123-130.

Navakkode S, Sajikumar S, Frey JU (2004) The type IV-specific phosphodiesterase inhibitor rolipram and its effect on hippocampal long-term potentiation and synaptic tagging. J Neurosci 24:7740-7744.

Neer EJ (1997) Intracellular signalling: turning down G-protein signals. Curr Biol 7:R3133.

Nomoto S, Adachi K, Yang LX, Hirata Y, Muraguchi S, Kiuchi K (1997) Distribution of RGS4 mRNA in mouse brain shown by in situ hybridization. Biochem Biophys Res Commun 241:281-287.

Paxinos G, Watson C (2007) The rat brain in stereotaxic coordinates. San Diego: Academic press.

Picot MC, Baldy-Moulinier M, Daures JP, Dujols P, Crespel A (2008) The prevalence of epilepsy and pharmacoresistant epilepsy in adults: a population-based study in a Western European country. Epilepsia 49:1230-1238.

Racine RJ (1972) Modification of seizure activity by electrical stimulation. II. Motor seizure. Electroencephalogr Clin Neurophysiol 32:281-294.

Sadegh M, Mirnajafi-Zadeh J, Javan M, Fathollahi Y, Mohammad-Zadeh M, Jahanshahi A, Noorbakhsh SM (2007) The role of galanin receptors in anticonvulsant effects of low-frequency stimulation in perforant path-kindled rats. Neuroscience 150:396-403.

Schiller Y, Bankirer Y (2007) Cellular mechanisms underlying antiepileptic effects of low- and high-frequency electrical stimulation in acute epilepsy in neocortical brain slices in vitro. J Neurophysiol 97:1887-1902.

Schrader LM, Stern JM, Wilson CL, Fields TA, Salamon N, Nuwer MR, Vespa PM, Fried I (2006) Low frequency electrical stimulation through subdural electrodes in a case of refractory status epilepticus. Clin Neurophysiol 117:781-788.

Schwalb JM, Hamani C (2008) The history and future of deep brain stimulation. Neurotherapeutics 5:3-13. 
Schwendt M, McGinty JF (2007) Regulator of G-protein signaling 4 interacts with metabotropic glutamate receptor subtype 5 in rat striatum: relevance to amphetamine behavioral sensitization. J Pharmacol Exp Ther 323:650-657.

Shahpari M, Mirnajafi-Zadeh J, Firoozabadi SM, Yadollahpour A (2012) Effect of lowfrequency electrical stimulation parameters on its anticonvulsant action during rapid perforant path kindling in rat. Epilepsy Res 99:69-77.

Shigeru I (1983) Experimental seizure model induced by dibutyryl derivatives of cyclic nucleotides. J Jpn Epil Soc 1:88-98.

Taymans JM, Wintmolders C, Te Riele P, Jurzak M, Groenewegen HJ, Leysen JE, Langlois X (2002) Detailed localization of regulator of $G$ protein signaling 2 messenger ribonucleic acid and protein in the rat brain. Neuroscience 114:39-53.

Thalmann RH, Ayala GF (1982) A late increase in potassium conductance follows synaptic stimulation of granule neurons of the dentate gyrus. Neurosci Lett 29:243248.

Tuff LP, Racine RJ, Adamec R (1983) The effects of kindling on GABA-mediated inhibition in the dentate gyrus of the rat. I. Paired-pulse depression. Brain Res 277:79-90.

Upreti C, Zhang XL, Alford S, Stanton PK Role of presynaptic metabotropic glutamate receptors in the induction of long-term synaptic plasticity of vesicular release. Neuropharmacology 66:31-39.

Velisek L, Veliskova J, Stanton PK (2002) Low-frequency stimulation of the kindling focus delays basolateral amygdala kindling in immature rats. Neurosci Lett 326:6163.

Xie K, Martemyanov KA (2011) Control of striatal signaling by g protein regulators. Front Neuroanat 5:49.

Xu JY, Chen R, Zhang J, Chen C (2010) Endocannabinoids differentially modulate synaptic plasticity in rat hippocampal CA1 pyramidal neurons. PLoS One 5:e10306.

Zhang M, Storm DR, Wang H (2011) Bidirectional synaptic plasticity and spatial memory flexibility require Ca2+-stimulated adenylyl cyclases. J Neurosci 31:1017410183. 


\section{Figure Legends}

Figure 1. Time-line diagram showing the experimental protocol used in kindled, LFS and kindled+LFS groups.

Figure 2. Effect of rolipram microinjection $(0.25 \mu \mathrm{M})$ on preventing action of LFS on kindling development. A) There was a significant decrease in the behavioral seizure stages during day 4 to day 6 in the kindled+LFS+vehicle (KLFS+vehicle) $(n=6)$ compared with the kindled+vehicle group $(n=6)$. Microinjection of Rolipram (in KLFS+Rolipram group; $n=6$ ) decreased the effect of LFS on the acquisition of seizure stages so that there was significant difference between KLFS+vehicle and KLHS+rolipram, B) Rolipram microinjection prevented the inhibitory effect of LFS on cumulative afterdischarge duration (ADD) during kindling development. Values are presented as mean \pm S.E.M. ${ }^{*} p<0.05,{ }^{* *} p<0.05$ and ${ }^{* * *} p<0.001$ when compared with kindled+vehicle group. \# $\mathrm{p}<0.05, \# \# \mathrm{p}<0.01$ and \# \# \# $<<0.001$ when compared with KLFS+vehicle group.

Figure 3. Effect of Rolipram microinjection $(0.25 \mu \mathrm{M})$ on the inhibitory action of LFS on kindling induced potentiation in population spike (PS) amplitude and population excitatory post-synaptic potential (pEPSP) slope. A) Sample averages of 12 wave-forms taken on day 1 and 6 in kindled+vehicle, KLFS+vehicle and KLFS+rolipram groups. The slope of pEPSP was determined at a fixed interval beginning approximately $1.0 \mathrm{~ms}$ after response onset and continuing within approximately $0.2 \mathrm{~ms}$ before PS onset (line a in left upper trace). B) Time-course diagrams showing the changes in PS amplitude and pEPSP slope in kindled+vehicle $(n=6), \operatorname{KLFS}+$ vehicle $(n=6)$ and KLFS+CPT $(n=6)$ 
groups during 6 days kindling stimulations. Each graph shows 20 min baseline perforant path evoked responses recorded before kindling stimulation on different days.

Application of LFS-inhibited kindling induced potentiation (reveals as increase in PS amplitude and pEPSP slope in kindled+vehicle group). Microinjection of rolipram in the KLFS+rolipram group reduced the inhibitory effect of LFS on kindling induced potentiation. C) The $\%$ of increase in pEPSP slope and PS amplitude after 6 days of kindling stimulation is drawn as bar histogram. There was a significant difference between kindled+vehicle and KLFS+vehicle groups. However, microinjection of rolipram decreased the inhibitory effect of LFS significantly so that there was no significant difference between KLFS+rolipram and kindled+vehicle groups, but there was significant difference between KLFS+rolipram and KLFS+vehicle groups. Values are presented as mean \pm S.E.M. ${ }^{* * *} p<0.001$ when compared to the kindled+vehicle group. $\# p<0.05$ and \# \# \# $p<0.001$ when compared to the KLFS+vehicle group.

Figure 4. Effect of Rolipram microinjection $(0.25 \mu \mathrm{M})$ on the inhibitory influence of LFS on kindling induced changes in paired-pulse indices. A) Plot of paired pulse index (second PS/first PS×100) values obtained for different interpulse intervals in kindled+vehicle (upper; $n=6$ ), KLFS+vehicle (middle; $n=6$ ) and KLFS+rolipram (lower; $\mathrm{n=6)}$ groups. LFS application prevented the increase in early and late paired pulse depression and the decrease in paired pulse facilitation (compare upper and middle graphs). Microinjection of rolipram in KLFS+rolipram group decreased the inhibitory effect of LFS on kindling induced changes in paired pulse indices (compare middle and lower graphs). B) The percentage changes of paired-pulse index of experimental groups on day 6 (relative to day 1 ) at 3 selected interpulse intervals in which early paired pulse 
depression (30 ms), paired pulse facilitation $(70 \mathrm{~ms})$ and late paired pulse depression (300 ms) occurs. Microinjection of rolipram significantly reduced the suppressive effect of LFS on kindling-induced changes in paired-pulse indices. Values are presented as mean \pm S.E.M. ${ }^{*} p<0.05$ when compared with kindled+vehicle group.

Figure 5. (A) Representative images for the expression of $G_{\mathrm{as}}, G_{\mathrm{q} i / o}$, regulators of $\mathrm{G}$ protein signaling (RGS) proteins type RGS2, RGS4 and RGS10 in dentate gyrus of control, kindled, kindled+LFS (KLFS) and LFS groups at $24 \mathrm{~h}$ post-kindling stimulation as measured by Western blotting. $\beta$-actin was used as an internal control. (B-F) Changes in the expression level of $\mathrm{G}_{\mathrm{as}}, \mathrm{G}_{\mathrm{ai} / \mathrm{o}}, \mathrm{RGS2}$, RGS4 and RGS10 proteins in different experimental groups. Application of LFS during kindling procedure (KLFS group) prevented the kindling induced-decrease in RGS2 expression and decreased the expression of RGS4 and RGS10 proteins. Application of LFS alone had no significant effect on proteins expression. Values are presented as Mean \pm S.E.M.; $n=4 ;{ }^{* * *} \mathrm{P}<0.001$ when compared with control group.

Figure 6. A block diagram drawing of the anticonvulsant effect of LFS on kindlinginduced synaptic potentiation based on results of the present and our previous studies (Mohammad-Zadeh et al., 2007; Mohammad-Zadeh et al., 2009). Kindling stimulation can result in increasing the CAMP level by reducing the expression of RGS2 protein (line 1). Our previous study also showed that cAMP level increases following kindling stimulation (line 2). An increase in cAMP level may have a role in synaptic potentiation during seizure induction (line 3). On the other land, application of LFS reduces the expression on RGS4 and RGS10 proteins (line 4). Meanwhile, it prevents the kindling- 


$$
\begin{aligned}
& \text { induced increase in RGS2 protein expression (line 5). Therefore, LFS application can } \\
& \text { inhibits the increment in cAMP level. Injection of rolipram reduces the inhibitory action of } \\
& \text { LFS through blocking phosphodiesterase (PDE) activity (line 6). However, the LFS } \\
& \text { antiepileptogenic effects may mediate through other unknown mechanisms (line 7). } \\
& \text { GPCR: G protein coupled receptor; AC: Adenylyl cyclase; PDE: Phosphodiesterase }
\end{aligned}
$$


Figure 1

Figure 1

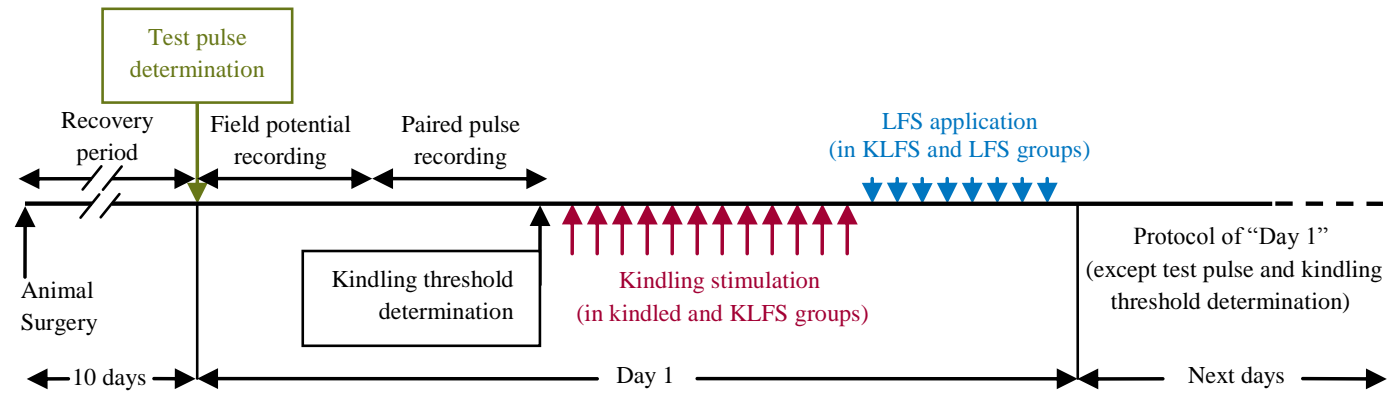

LFS application (in KLFS and LFS groups)
Protocol of "Day 1"

pulse and kindling

Next days 
Figure 2

A
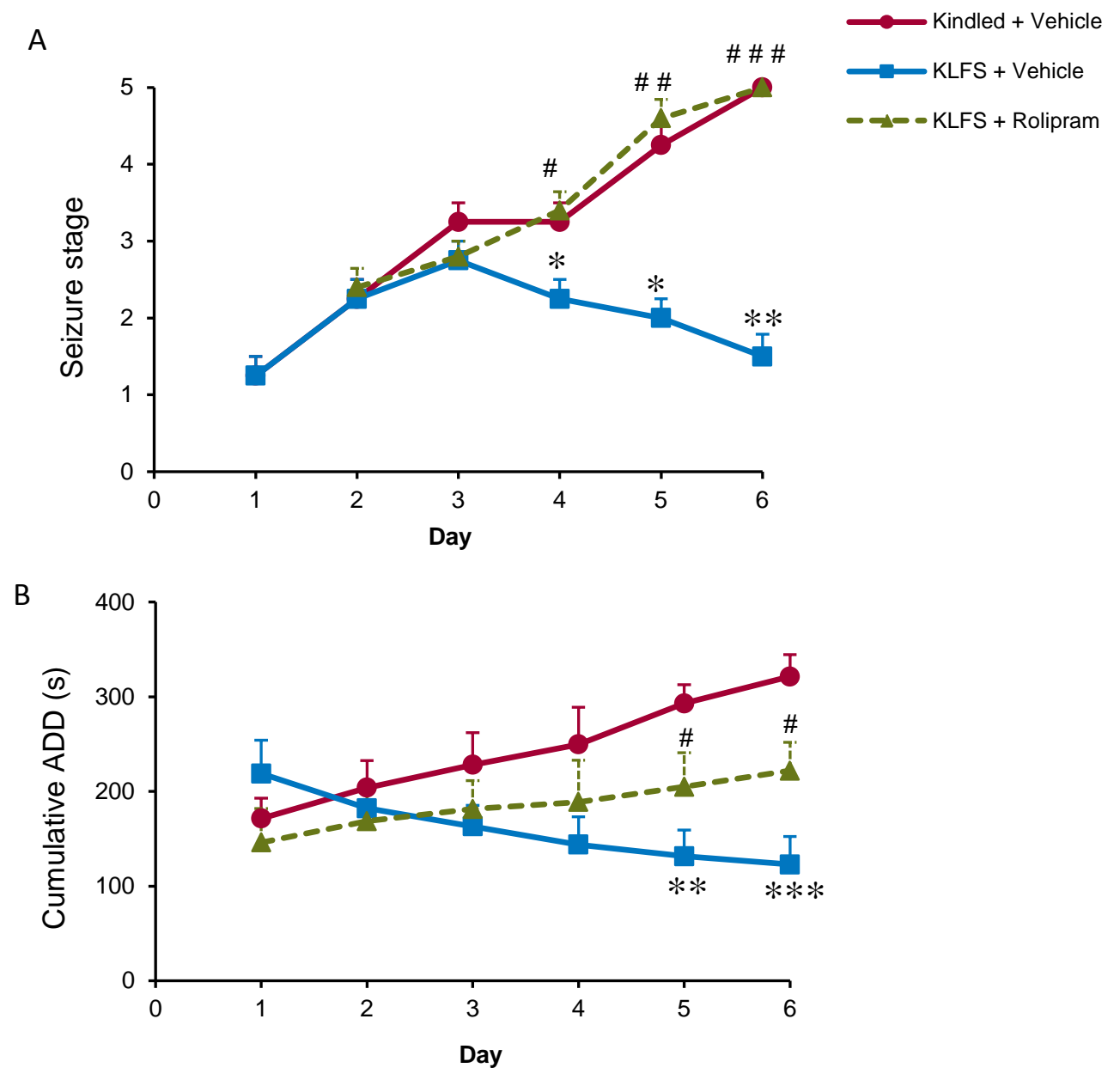

Figure 2 
Figure 3

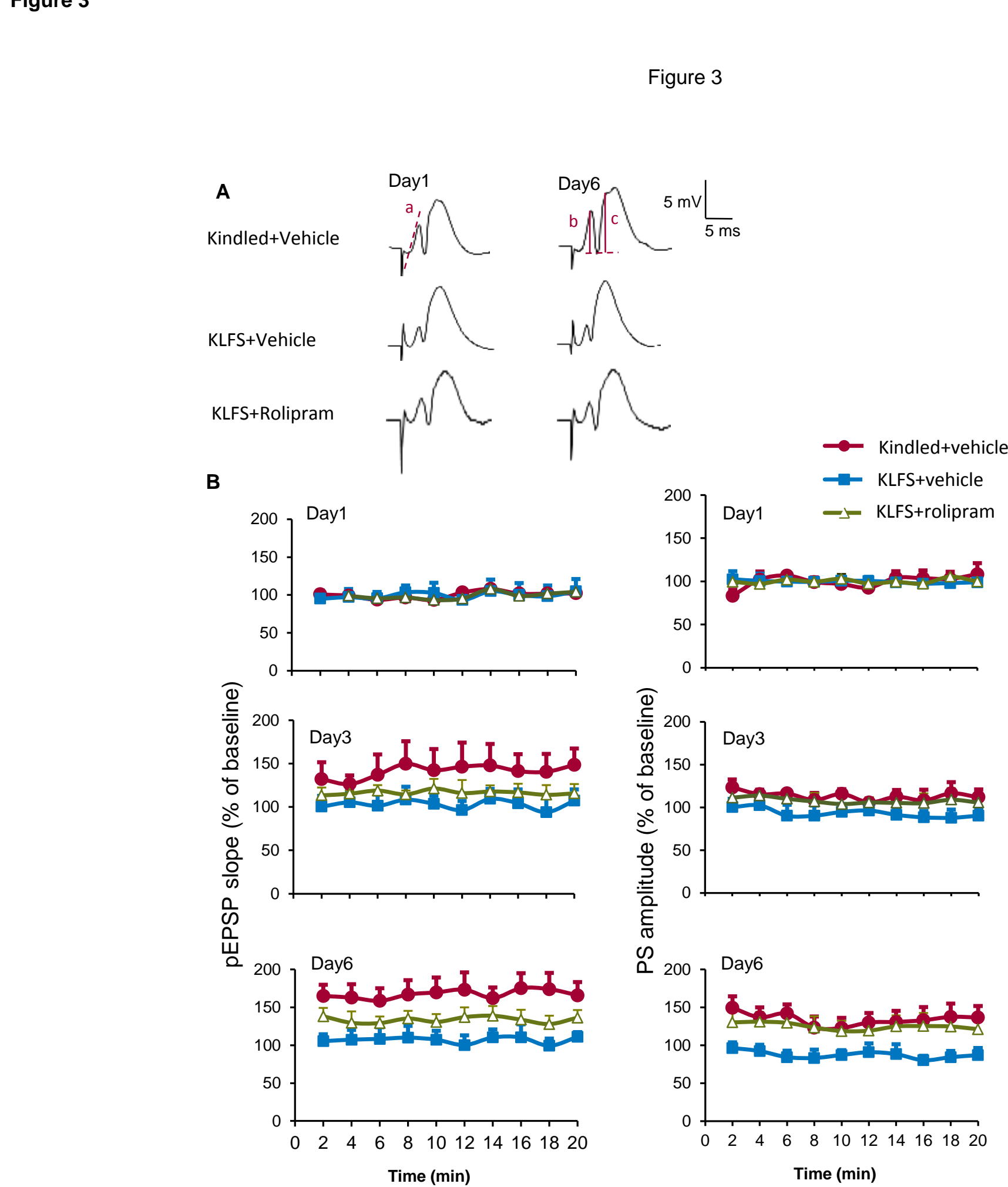

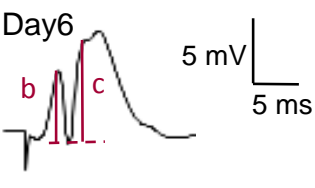
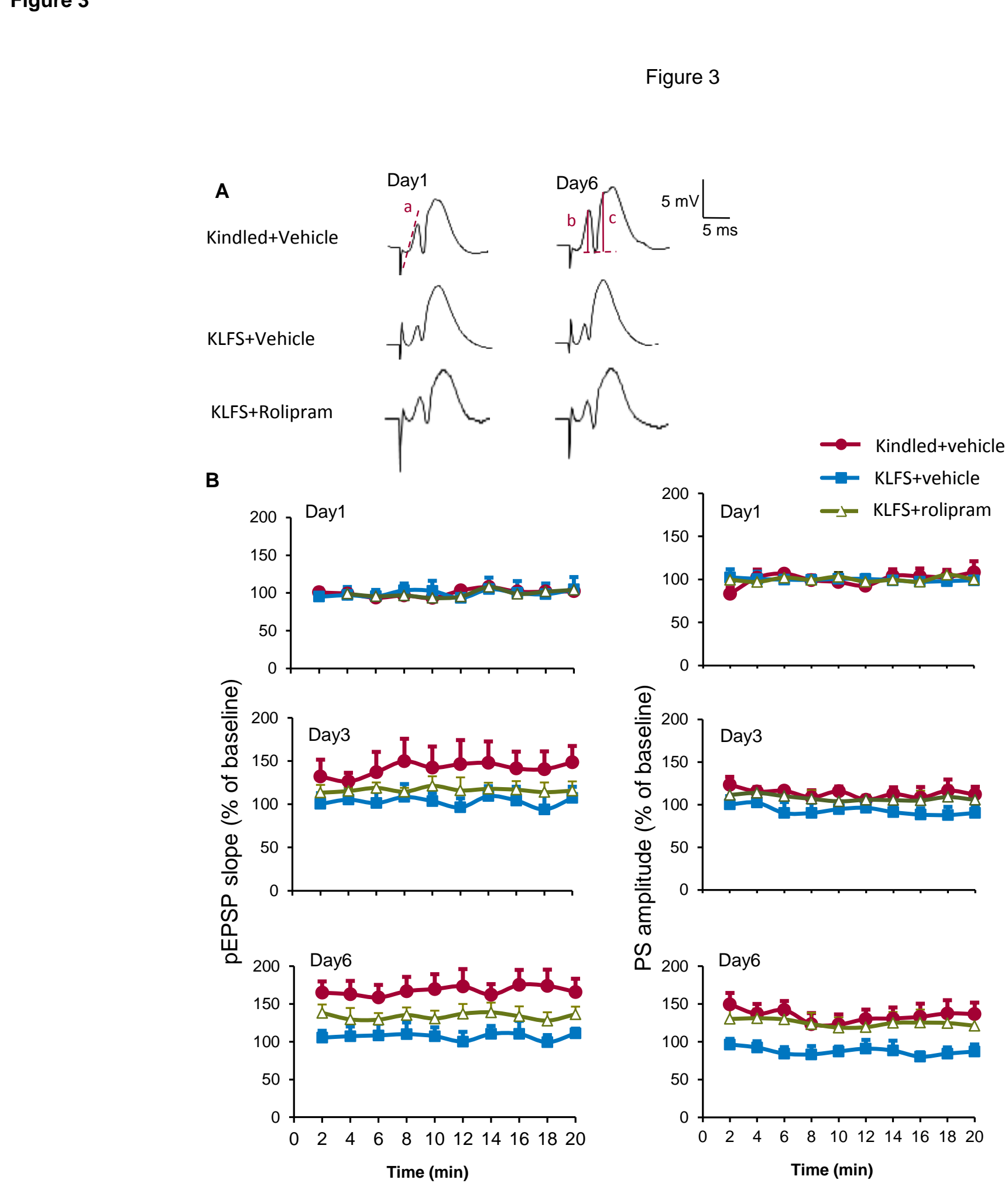

C

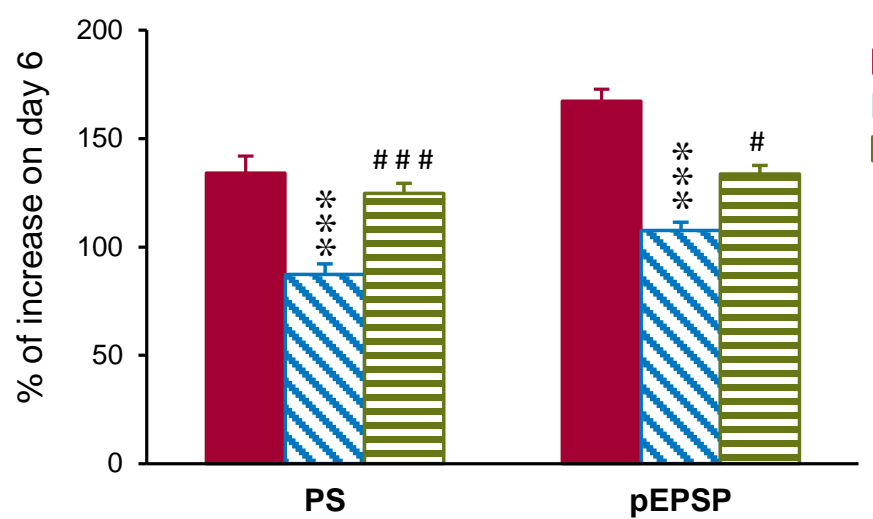

Kindled+vehicle

\KLFS+vehicle

$\boxminus$ KLFS+rolipram

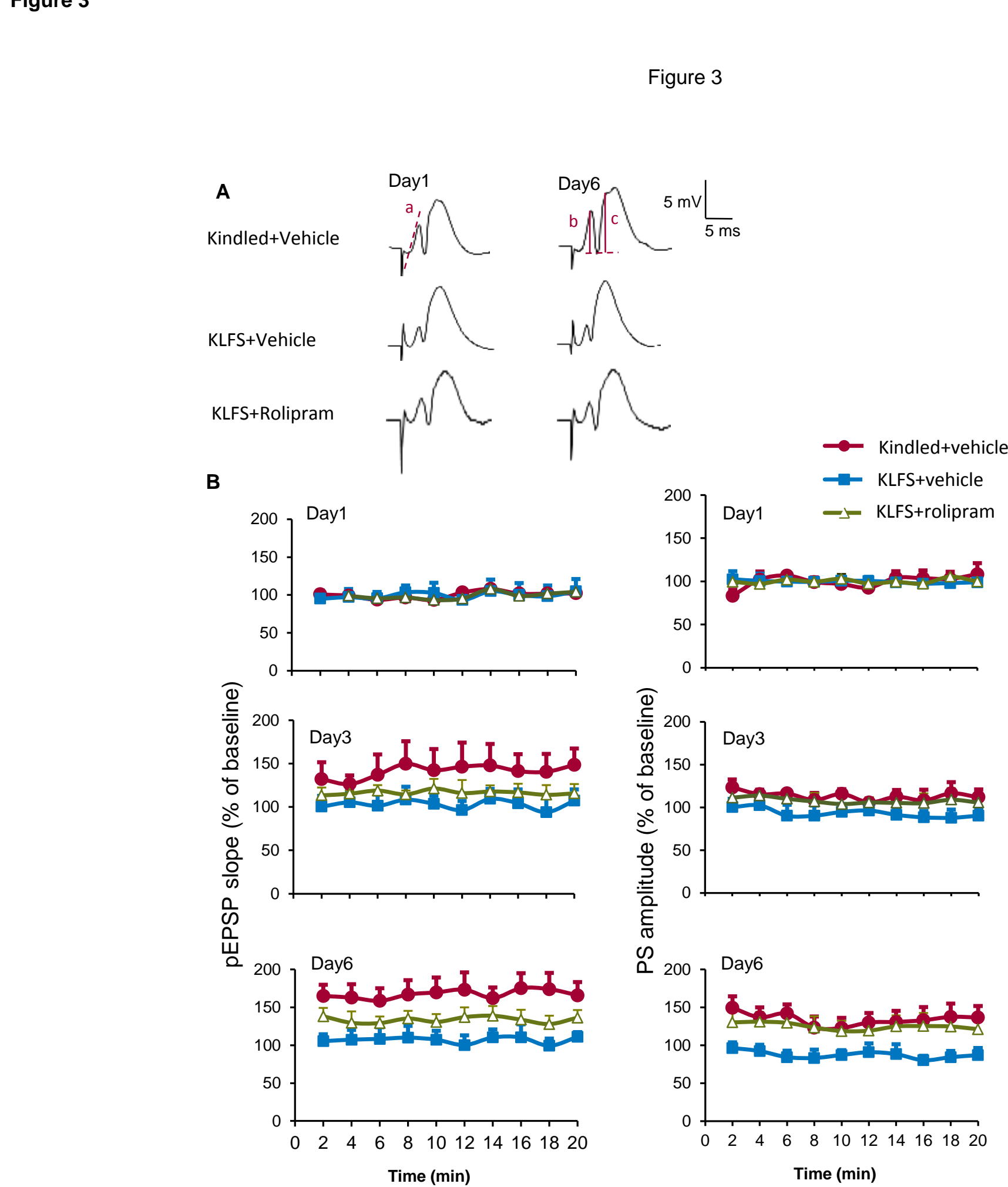

PS

pEPSP 

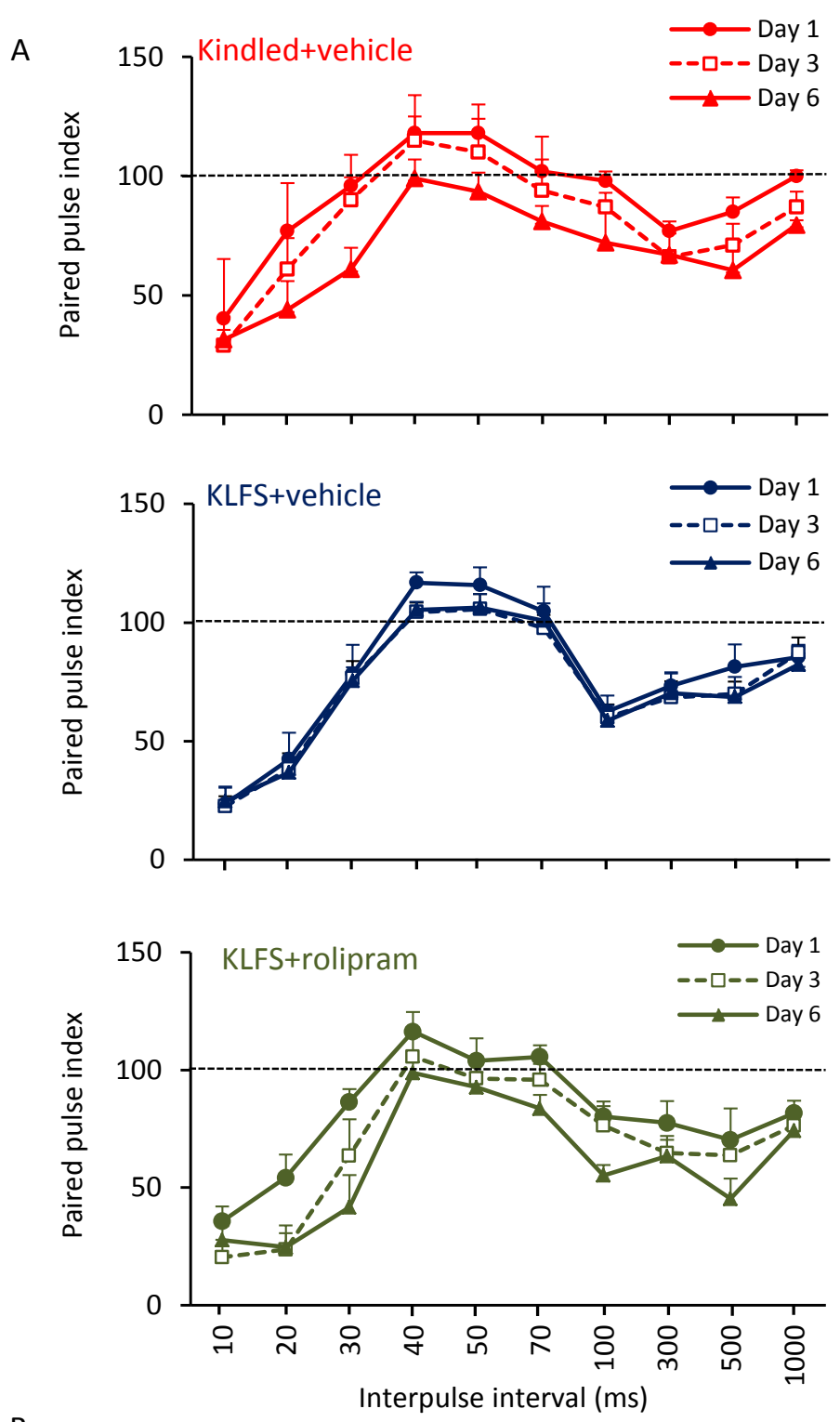

B

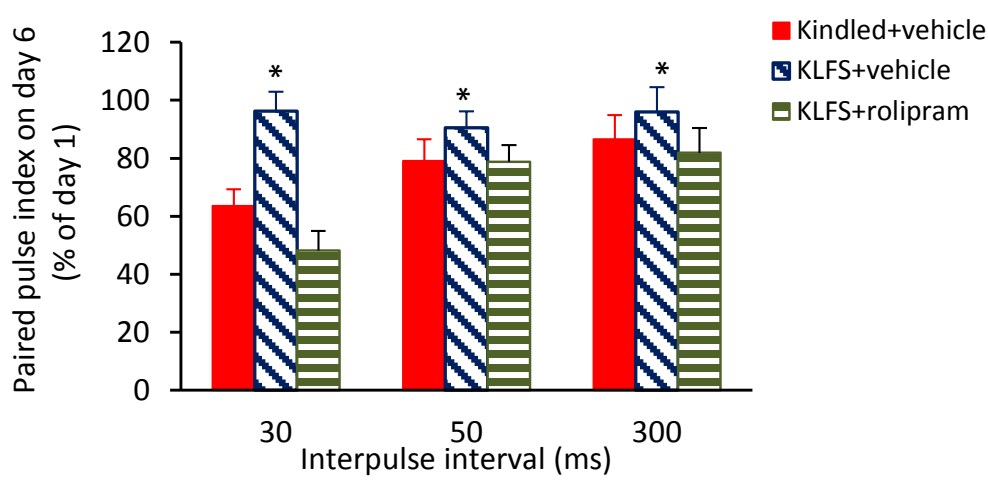


Figure 5

Figure 4
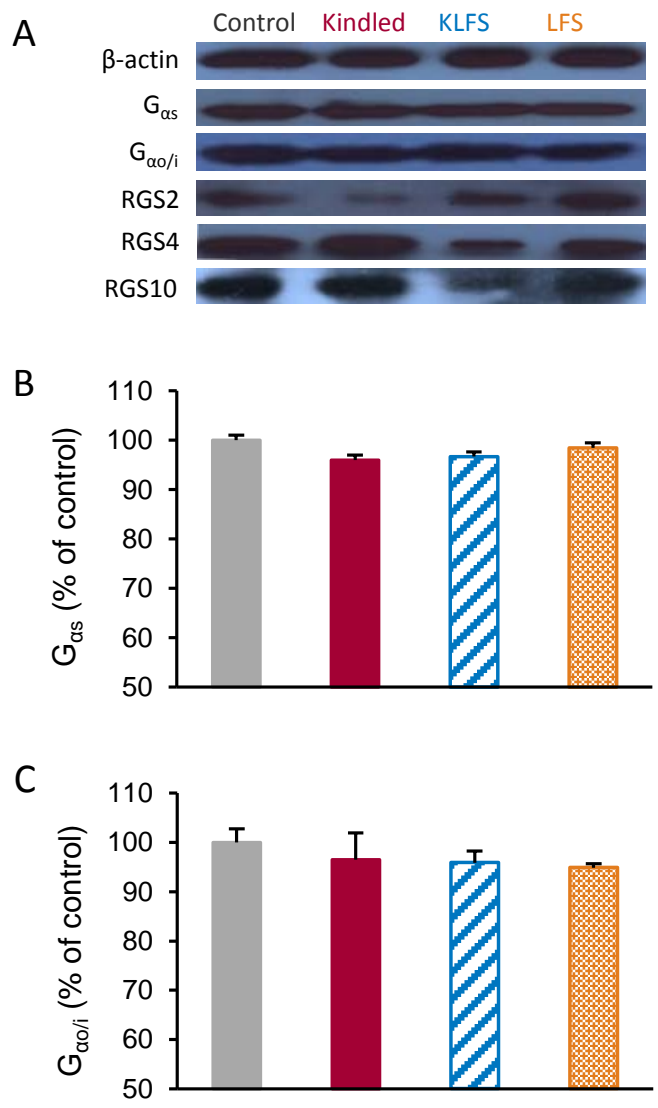

D
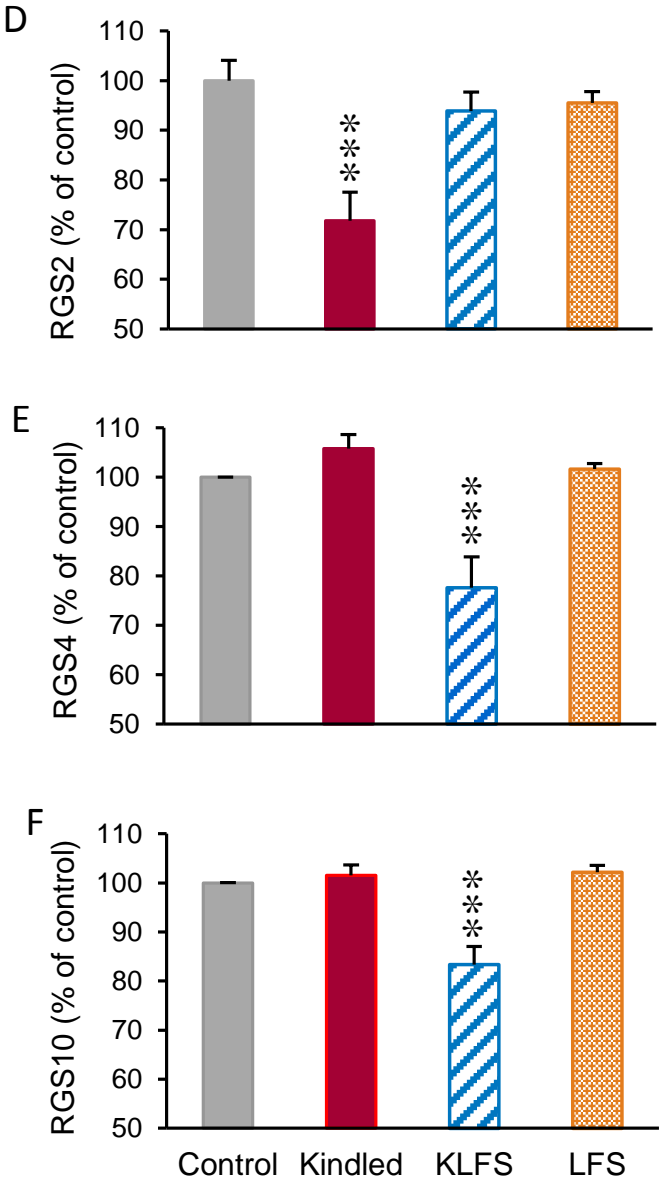


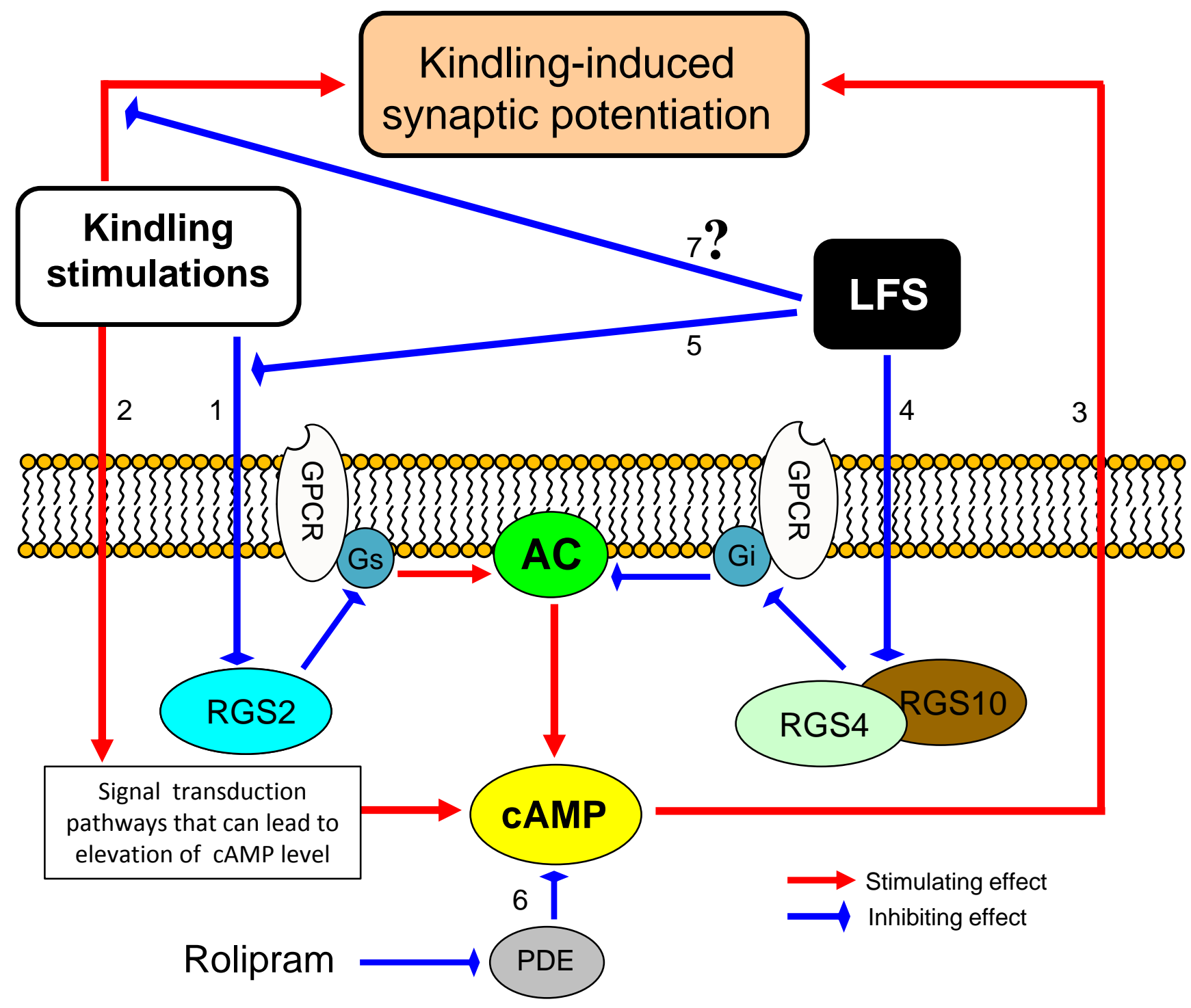

